\title{
Correlation between surface chemistry and settlement behaviour in barnacle cyprids (Balanus improvisus)
}

A. Di Fino, Luigi Petrone, N. Aldred, Thomas Ederth, Bo Liedberg and A. S. Clare

\author{
Linköping University Post Print
}

Tweet

N.B.: When citing this work, cite the original article.

This is an electronic version of an article published in:

A. Di Fino, Luigi Petrone, N. Aldred, Thomas Ederth, Bo Liedberg and A. S. Clare, Correlation between surface chemistry and settlement behaviour in barnacle cyprids (Balanus improvisus), 2014, Biofouling (Print), (30), 2, 143-152.

Biofouling (Print) is available online at informaworldTM:

http://dx.doi.org/10.1080/08927014.2013.852541

Copyright: Taylor \& Francis: STM, Behavioural Science and Public Health Titles http://www.tandf.co.uk/journals/default.asp

Postprint available at: Linköping University Electronic Press http://urn.kb.se/resolve?urn=urn:nbn:se:liu:diva-104280 


\title{
Correlation between surface chemistry and settlement behaviour in barnacle cyprids (Balanus improvisus).
}

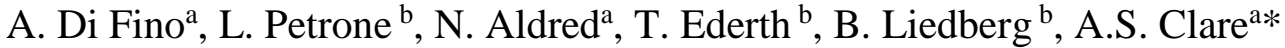 \\ ${ }^{a}$ School of Marine Science and Technology, Newcastle University, Newcastle upon Tyne, NE1 \\ $7 R U, U K$ \\ ${ }^{b}$ Division of Molecular Physics, Department of Physics, Chemistry and Biology, Linköping \\ University, Linköping, SE-581 83, Sweden \\ *Corresponding author: tony.clare@ncl.ac.uk
}

\begin{abstract}
In laboratory-based biofouling assays, the influence of physicochemical surface characteristics on barnacle settlement has been tested most frequently using the model organism Balanus amphitrite (=Amphibalanus amphitrite). Very few studies have addressed the settlement preferences of other barnacle species, such as B. improvisus (=A. improvisus). This study aims to unravel the effects of surface physicochemical cues, in particular surface free energy (SFE) and surface charge, on the settlement of B. improvisus cyprids. The use of well-defined surfaces under controlled conditions further facilitate comparison of the results with recent similar data for $B$. amphitrite. Zero-day old cyprids of B. improvisus were exposed to a series of model surfaces, namely self-assembled monolayers (SAMs) of alkanethiols with varying end-groups, homogenously applied to gold-coated polystyrene Petri dishes. As with B. amphitrite, settlement of B. improvisus cyprids was influenced by both SFE and charge, with higher settlement on low-energy (hydrophobic) surfaces and negatively-charged SAMs. Positivelycharged SAMs resulted in low settlement, with intermediate settlement on neutral SAMs of similar SFE. In conclusion, it is demonstrated that despite previous suggestions to the contrary, these two species of barnacle show similar preferences in response to surface free energy; they also respond similarly to charge. These findings have positive implications for the development of novel antifouling coatings and support the importance of consistency in substrate choice for assays designed to compare surface preferences of fouling organisms.
\end{abstract}

\section{Keywords}

Cyprid, antifouling, Balanus improvisus, self-assembled monolayer, surface energy, surface charge.

Published in Biofouling, 30(2), 143-152 (2014).

DOI: $\underline{10.1080 / 08927014.2013 .852541}$ 


\section{Introduction}

Increasing regulation of biocides for marine antifouling applications has led to growing interest in novel strategies to avoid the undesirable accumulation of marine fouling organisms on submerged man-made structures (Clare 1998; Yebra et al. 2004; Bressy et al. 2012). In aqueous environments, the capacity of materials to wet and de-wet plays an important role in the interfacial dynamics between the substrate, water and adhesives of fouling organisms (Aldred et al. 2013; Petrone 2013). Such sessile organisms have developed specialised sensory systems that enable them to find optimal substrates via detection of surface physicochemical features (Clare \& Nott 1994; Callow et al. 2005; Aldred et al. 2006; Bielecki et al. 2009; Stewart et al. 2011). Many fouling organisms, such as barnacles and mussels, have evolved adhesive secretions with superior abilities compared to synthetic glues, to attach to submerged surfaces with diverse properties (Nott 1969; Clare et al. 1994; Ödling et al. 2006; Stewart et al. 2011; Kamino 2013). These highly specialised glues thus allow fouling organisms to cope with the unpredictability of surfaces found in the marine environment (Nott \& Foster 1969; Walker \& Yule 1984; Aldred \& Clare 2008; Aldred et al. 2011; Maruzzo et al. 2011).

Understanding the settling behaviour of fouling larvae during the initial stages of colonization as well as the innate criteria they use to discriminate between surfaces (Matsumura et al.1998; Andersson et al. 1999; Berntsson et al. 2004; Murosaki et al. 2009) will play an important role in the development of antifouling coatings. Barnacles are one of the most thoroughly studied groups of fouling organisms due to their significant economic impact and relative simplicity of rearing in the laboratory (Holm 2012). In particular, the sub-tropical species Balanus amphitrite has been adopted as a widely-used model organism for testing the performance of coatings under development (Aldred \& Clare 2008; Clare \& Aldred 2009). However, this focus on a single problematic species may have been to the detriment of a broader understanding of barnacle fouling ecology. Looking at the twelve well-defined zones in the world's oceans described by Woods Hole (1952), variations in salinity, clarity, temperature, and micronutrients clearly point to different adaptations of various species in different places. It is thus important to broaden studies of other relevant fouling species, to test further the assumption that $B$. amphitrite is a suitable model. In particular, it is unclear whether or not surface preferences observed in the case of cyprids of $B$. amphitrite hold true for other common fouling species, such as B. improvisus. B. amphitrite and B. improvisus are cosmopolitan species, with overlapping distributions (e.g. Moore \& Frue 1959). B. amphitrite is a tropical/sub tropical species, whereas B. improvisus can tolerate colder waters, e.g. the Baltic Sea, and lower salinities, extending to the upper reaches of estuaries (Carlton et al. 2011).

Although the settlement behaviour of B. improvisus has been studied with regard to varying environmental conditions (Berntsson \& Jonsson 2003; Jonsson et al. 2004) and different surface properties (Dahlström et al. 2000; 2004; Pinori et al. 2013), our understanding of the settlement behaviour and surface preferences of $B$. improvisus lags far behind $B$. amphitrite. Perhaps the most thoroughly studied aspect of $B$. improvisus settlement behaviour is the response of cyprids to surface topography (Andersson et al. 1999, Berntsson et al. 2000a; 2000b; Berntsson et al. 2004). Many surface features used in antifouling research have been designed to be biomimetic, inspired by the naturally occurring external structures of foulingfree organisms (Salta et al. 2010; Scardino \& de Nys 2011). Such structures are reproduced as 3-dimensional patterned surfaces fabricated from synthetic polymers (e.g. Murosaki et al. 2009, Aldred et al. 2010b; Ahmed et al. 2011; Greco et al. 2013; del Campo 2013). Using such surfaces, Aldred et al. (2010b) demonstrated similar effects on the settlement of cyprids of $B$. amphitrite as had been observed previously for B. improvisus. For both species, features of the same order of magnitude as the cyprid body, but slightly smaller, reduced settlement by up to 
$100 \%$. It appears, therefore, that the response of cyprids of the two species to the physical nature of the surface can be consistent in laboratory assays. The response to surface chemistry, however, is less clearly defined. The prevailing view that cyprids of $B$. amphitrite exhibit a strong preference for high energy surfaces (Finlay et al. 2010) was recently questioned by Petrone et al. (2011), who found instead a preference for low-energy surfaces when experimental bias was removed. Cyprids of $B$. amphitrite also showed a strong response to surface charge, settling in greater number on negatively charged surfaces with very low settlement on positively charged ones.

Over the years, many studies have aimed at a better understanding of the effects of surface parameters such as SFE on the settlement behaviour of barnacles. The reason for this continued interest is that SFE in particular has frequently been linked to the efficacy of foulingrelease coatings (Callow \& Fletcher, 1994). This position was arrived at based both on theory and empirical evidence, having been correlated directly to the adhesion of marine organisms (Lindner 1992; Meyer \& Baier, 1992). Low SFE is undoubtedly a useful characteristic in a surface designed to prevent adhesion, with the so-called 'Baier minimum' (Baier 1973; Dexter 1979) between $20-30 \mathrm{mN} \mathrm{m}^{-2}$ providing minimal adhesion. The question is whether barnacle cyprids perceive differences in surface chemistry, in terms of charge or SFE, and settle accordingly. If the response is conserved between species across diverse habitats this would be an advantage in the design of 'non-stick' marine coatings. If, however, different barnacle species from different locales respond differently to such surface characteristics this would present an obstacle to the design of novel non-fouling materials. Historically, the latter has been presumed to be the case, based upon observations of the settlement of cyprids from different species on a range of experimental surfaces.

Significant effects of surface chemistry have been demonstrated repeatedly in the literature, however as discussed by Petrone et al. (2011), these former studies share a common disadvantage in that the surfaces used in laboratory-based settlement assays often differed in more than one respect, confusing the interpretation. For example, O'Connor and Richardson (1994) found that settlement of B. improvisus cyprids was higher on polystyrene compared to glass. Glass is a high-SFE material and polystyrene generally has low SFE, but the two materials also differ in several other ways that may also be perceived by exploring cyprids, such as surface roughness and different chemical features. The apparent preference of $B$. amphitrite for hydrophilic surfaces was reported in a number of studies, (Rittschof \& Costlow 1989; O’Connor \& Richardson 1994; Gerhart et al. 1992). However, similar experiments conducted using $B$. improvisus demonstrated an opposite tendency for settling on hydrophobic (low SFE) surfaces (Dahlström et al. 2004). Maki et al. (1994) highlighted the absence of a correlation between surface wettability and temporary adhesion strength of $B$. amphitrite cyprids. The apparent difference in surface selectivity between these two species thus became a point of interest.

The present study aimed to identify the response of cyprids of B. improvisus to a range of model surfaces (self-assembled monolayers) with varying SFE and surface charge in order to compare the response to that of $B$. amphitrite for the first time in a controlled manner. Furthermore, the effect of cyprid age on the settlement behaviour of B. improvisus was evaluated using sealed polystyrene Petri dishes to reduce the phenomenon of floating cyprids, as proposed by Qiu et al. (2008). The results from this work have the potential to guide the development of novel environmentally-friendly antifouling coatings by repelling cyprids during the initial stages of surface colonization. 


\section{Materials and Methods}

Culture of cyprids. Adult Balanus improvisus were supplied by the Department of Biological and Environmental Sciences, The Sven Lovén Centre for Marine Sciences, Tjärnö University of Gothenburg, Sweden, and reared in the laboratory at Newcastle University. The larvae released from the first stock of adults were cultured and used to obtain new broodstock barnacles on panels of Plexiglass.

Barnacles were maintained in artificial seawater (Tropic-Marin ${ }^{\circledR} 22$ ) at $19 \pm 2{ }^{\circ} \mathrm{C}$. Adults were cleaned by brushing and the seawater was changed every two days. Adult broodstocks were allowed to release nauplii naturally yielding approximately 10,000 stage-1 nauplii over a period of 3 to $4 \mathrm{~h}$. The nauplii were attracted to a cold light source and transferred at intervals to a dilute solution of Thalassiosira pseudonana for temporary storage. When a sufficient number had been collected, the nauplii were transferred to a clean plastic bucket containing $10 \mathrm{~L}$ of $0.7 \mu \mathrm{m}$ filtered artificial seawater (ASW) with $36.5 \mathrm{mg} \mathrm{L}^{-1}$ of streptomycin sulphate and $21.9 \mathrm{mg} \mathrm{L}^{-1}$ of penicillin $\mathrm{G}$ at $28{ }^{\circ} \mathrm{C}$. The larvae were fed an excess of a mixture of $70 \%$ T. pseudonana and $30 \%$ Tetraselmis suecica. After two days the solution was filtered and nauplii were stored in clean ASW with $50 \%$ of T. pseudonana and $50 \%$ of T. suecica for a further two days until metamorphosis to the cyprid stage. Cyprids were then filtered from the solution and transferred into ASW. Following filtration, 0-day-old cyprids were used to identify a suitable container in which to carry out assays, free from experimental bias, and subsequently to investigate the effect of varying surface energy and charge on cyprid settlement. Additionally, other cyprids from the same batch were stored at $6{ }^{\circ} \mathrm{C}$ and aged for up to 5 days for studying the effect of cyprid age on settlement.

Settlement assays. Cyprid settlement assays were conducted in sterile polystyrene (PS) Petri dishes (BD Falcon 1006, USA) filled to the brim with filtered seawater (14 mL maximum volume per dish) and subsequently sealed with a PS lid, ensuring that no air bubbles remained inside. This configuration avoided the issue, previously reported, of cyprids being trapped at the air/water interface during assays. For comparison, cyprid settlement assays were also conducted in 24-well PS tissue culture plates (TC Plate 24-Well F, Sarstedt, USA), which presented the organisms with an air/water interface.

Settlement assays in response to varying surface energy and charge were carried out in gold-coated Petri dishes, as described by Petrone et al. (2011). Briefly, both the bottoms and the lids of the Petri dishes were placed on a rotating sample holder, which was progressively inclined by a moving arm at an angle up to $30^{\circ}$ during metal evaporation, enabling metal deposition on both the side and the bottom (top) of the Petri dishes. Subsequently, filling the Petri dishes with the SAM incubation solutions (see below) ensured that the whole interior of the Petri dishes were homogeneously coated, and presented the same surface chemistry.

Assays were performed in 24-well PS plates with $2 \mathrm{~mL} \mathrm{FSW}$ and 20 cyprids, and in PS Petri dishes with 30 cyprids in $14 \mathrm{~mL} \mathrm{ASW}$ at a salinity of 22 . All assays were conducted in the dark at $28{ }^{\circ} \mathrm{C}$ with settlement of cyprids monitored at 24 and $48 \mathrm{~h}$. Settled cyprids were counted on the base, sides and lid of the Petri dish using 4 replicates for each surface.

Data analysis. Results are presented as means \pm standard error (SE). The effect of surface chemistry on settlement was examined by one-way analysis of variance (ANOVA) with Tukey pairwise comparisons using Minitab 15 and an alpha level of 0.05 .

A general linear model (GLM) was designed to test the effects of charge and SFE independently on the settlement of the two species (drawing upon raw data from Petrone et al. 2011), and to highlight any interactive effects. Under normal circumstances data would not be compared in this way between unrelated assays, however settlement on each surface was so 
similar between species (assays) that this approach was considered to be nonetheless rigorous and highly illustrative.

To balance the model, two levels of SFE energy were assumed 'low' including the $-\mathrm{CH}_{3}$ surface and 'high' including all other surfaces whose contact angles lay within a $10^{\circ}$ range (only surfaces with data for both species could be included in the model). The model allowed investigation of the effects of surface charge, SFE, species and the interactions between SFE and species, and charge and species. The interaction between SFE and charge could not be investigated due to the absence of low SFE charged surfaces. 'Species' was included as a covariate in the analysis.

Self-assembled monolayer preparation. Gold-coated substrates were immersed in $100 \mu \mathrm{M}$ thiol solutions in $99.5 \%$ ethanol (Kemetyl, Sweden). Thiols used to prepare SAMs were $\mathrm{HS}\left(\mathrm{CH}_{2}\right)_{15} \mathrm{CH}_{3}$ (1-hexadecanethiol) (Fluka Chemie, Switzerland), $\mathrm{HS}\left(\mathrm{CH}_{2}\right)_{16} \mathrm{OH}$ (16hydroxy-1-hexadecantehiol) (gift from Biacore AB, now GE Healtcare, Sweden) $\mathrm{HS}\left(\mathrm{CH}_{2}\right)_{11} \mathrm{~N}\left(\mathrm{CH}_{3}\right)_{3}{ }^{+} \mathrm{Cl}^{-}$(N,N,N-trimethyl-(11-mercaptoundecyl) ammonium chloride) (Prochimia, Poland), $\mathrm{HS}\left(\mathrm{CH}_{2}\right)_{16} \mathrm{NH}_{2}$ (16-amino-1-hexadecanethiol) (Prochimia, Poland), $\mathrm{HS}\left(\mathrm{CH}_{2}\right)_{11} \mathrm{PO}(\mathrm{OH})_{2}$ (11-mercapto-1-undecylphosphonic acid) (Prochimia, Poland), $\mathrm{HS}\left(\mathrm{CH}_{2}\right)_{11} \mathrm{SO}_{3} \mathrm{Na}$ (sodium 11-mercaptoundecanesulfonate) (Prochimia, Poland), and $\mathrm{HSC}_{6} \mathrm{H}_{4} \mathrm{COOH}$ (thiosalicylic acid, TSA) (Sigma-Aldrich, Sweden). After $24 \mathrm{hr}$ incubation in the dark and at room temperature, SAMs were rinsed three times with ethanol, sonicated for 3 min in ethanol and dried under $\mathrm{N}_{2}$ flow.

SAM characterization. Silicon ( $\mathrm{Si}$ ) wafers (Topsil Semiconductor Materials A/S) were cut into pieces and subsequently cleaned with TL1 solution (1:1:5 solution of $25 \% \mathrm{NH}_{3}$ (Merck, Germany), $30 \% \mathrm{H}_{2} \mathrm{O}_{2}$ (Merck, Germany), and Milli-Q (Millipore) water), for $10 \mathrm{~min}$ at $80{ }^{\circ} \mathrm{C}$ prior to coating first with a 30 Á-thick layer of titanium (Ti) (Balzers, Liechtenstein, 99.9\%) and then with a $2000 \AA$ thick Au layer (Nordic High Vacuum AB, Sweden, 99.9\%) at rates of 0.5 and $10 \AA \mathrm{s}^{-1}$, respectively.

An automatic null ellipsometer (Rudolph Research AutoEL III) equipped with a $\mathrm{He}-$ Ne laser $(\lambda=632.8 \mathrm{~nm})$ set at an incidence angle of $70^{\circ}$ was used to obtain the thickness of SAMs on gold-coated Si. SAM thicknesses were calculated from the measurement outputs $(\Delta$ and $\Psi$ ) using a three-layer parallel slab $\mathrm{Au} / \mathrm{SAM} /$ air model. An isotropic refractive index $n=1.50$ and $k=0$ was assumed for the SAM. The reported values were the averages of five measurements on each surface.

Advancing contact angles of SAMs on gold-coated Si were measured with a CAM 2000 Optical Contact Angle Meter (KSV Instruments Ltd, Finland) equipped with a manual liquid dispenser. The reported advancing contact angle values were the average of five measurements on different locations. Gibbs surface free energy was calculated as described in Petrone et al. (2011) using the Good-van Oss-Chaudhury (GvOC) model by measuring the advancing contact angle on SAMs with three liquids, namely water (W), glycerol (G) and diiodomethane (DIM). 


\section{Results}

Effect of container. Polystyrene 24-well plates were used to determine the percentage of cyprid (0-day-old) settlement after 24, 48 and $72 \mathrm{~h}$. Settlement was low at each observation, 5 $\pm 2 \%, 9 \pm 3 \%$ and $15 \pm 4 \%$ respectively (Fig. 1A). The low settlement values reflected the large number of cyprids 'floating' trapped in the liquid meniscus. Performing settlement assays in sealed Falcon 1006 Petri dishes, containing no trapped air, negated this issue and the mean percentage of settled cyprids increased to $46 \pm 11 \%$ after $48 \mathrm{~h}$ and $80 \pm 8 \%$ after $72 \mathrm{~h}$ (Fig. 1B).

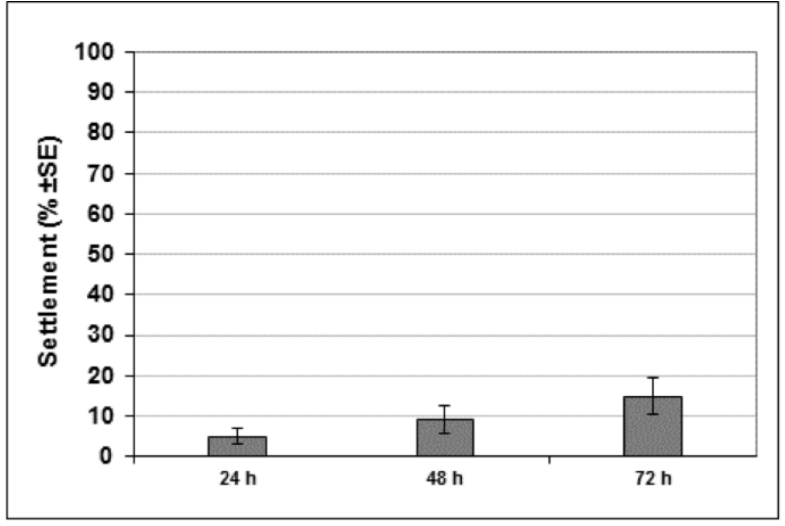

A

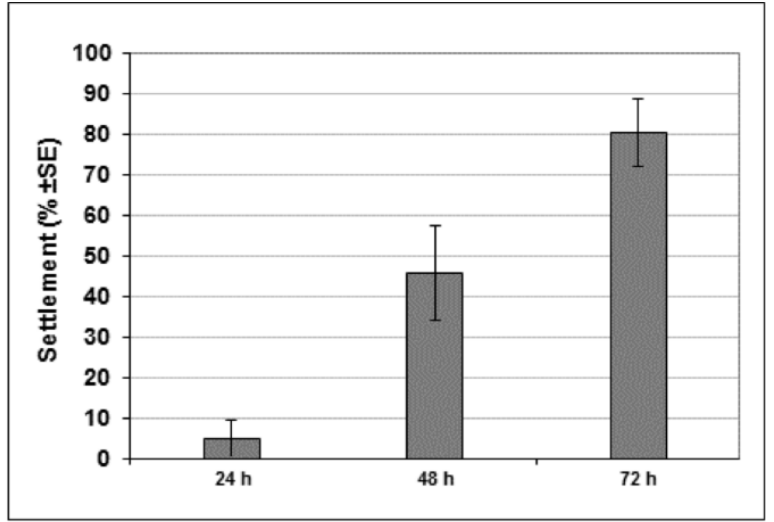

B

Figure 1. Mean percentage of cyprids (0-day-old) of Balanus improvisus settled after 24, 48 and $72 \mathrm{hr}$ on uncoated polystyrene, in (A) 24-well plates and (B) sealed Petri dishes.

Effect of cyprid age. Figure 2 shows the mean settlement percentage of different ages of cyprids, ranging from 0- to 5-days-old, after 24 and $48 \mathrm{~h}$ in PS Petri dishes. After $48 \mathrm{~h}$, the mean settlement percentages for $0,1,2,3,4$ and 5-day-old cyprids were $46 \pm 12 \%, 53 \pm 9 \%$, $51 \pm 5 \%, 34 \pm 3 \%, 28 \pm 11 \%$ and $60 \pm 3 \%$, respectively. Settlement data differed significantly between different ages of cyprid ( $p<0.05, F=4.46$ ) (ANOVA, Tukey test) and pairwise comparisons are presented in Figure 2. Cyprids 0, 1, 2 and 5 days post-metamorphosis settled in significantly higher numbers compared to cyprids 3 and 4 days post metamorphosis. Settlement after $24 \mathrm{~h}$ did not yield significant differences.

Settlement in response to varying surface energy and charge. Tests were conducted with 0-day-old cyprids as described in the literature (O'Connor and Richardson 1994, 1996; Berntsson et al. 2000b; Dahlström et al. 2000; Berglin et al. 2001). SAMs were prepared from positively-charged $\left(-\mathrm{N}\left(\mathrm{CH}_{3}\right)_{3}{ }^{+}\right.$and $\left.-\mathrm{NH}_{3}{ }^{+}\right)$, negatively-charged $\left(-\mathrm{SO}_{3}{ }^{-},-\mathrm{PO}_{3}{ }^{2-}\right.$ and $\left.-\mathrm{CO}_{2}{ }^{-}\right)$, and neutral hydrophilic and hydrophobic $\left(-\mathrm{OH}\right.$ and $\left.-\mathrm{CH}_{3}\right)$ tail groups. Thickness, advancing water contact angle with three liquids (W, DIM and G) and Gibbs surface energy for SAMs used in this work are reported in Table 1.

Settlement was enumerated at $48 \mathrm{~h}$ to allow comparison with previous studies. Cyprid mean settlement was $11 \pm 6 \%$ on the neutral and hydrophilic OH-SAM, and $47 \pm 4 \%$ on the neutral and hydrophobic $\mathrm{CH}_{3}$-SAM (Fig. 3). Settlement was $8 \pm 2 \%$ and $2 \pm 1 \%$ on the positively charged $\mathrm{N}\left(\mathrm{CH}_{3}\right)_{3}{ }^{+}$- and $\mathrm{NH}_{3}{ }^{+}$-SAM, respectively. Cyprid settlement was highest on the negatively charged surfaces with average percentages of $44 \pm 4 \%$ on $\mathrm{SO}_{3}{ }^{-}, 49 \pm 2 \%$ on $\mathrm{PO}_{3}{ }^{2-}$ - and $43 \pm 5 \%$ on $\mathrm{CO}_{2}{ }^{-}$-SAM. Settlement data differed significantly between surfaces $(p$ $<0.05, F=30.42$ ) at $95 \%$ confidence (ANOVA, Tukey method). 


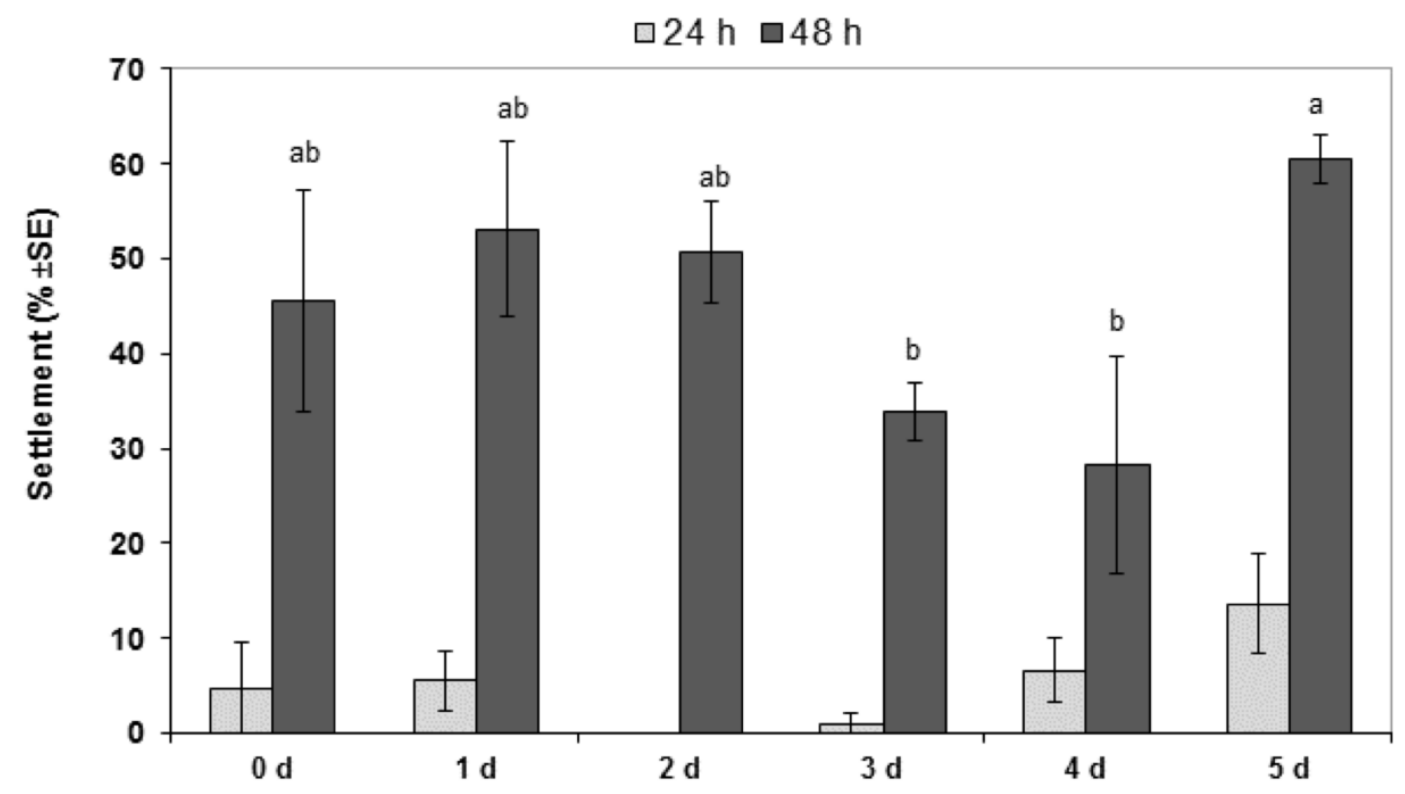

Figure 2. Mean settlement percentages cyprids of B. improvisus from 0- to 5-days-old in uncoated PS Petri dishes after 24 and $48 \mathrm{hr}$ in FSW (salinity =20). Results of Tukey pairwise comparisons are presented. Means that do not share a letter are significantly different.

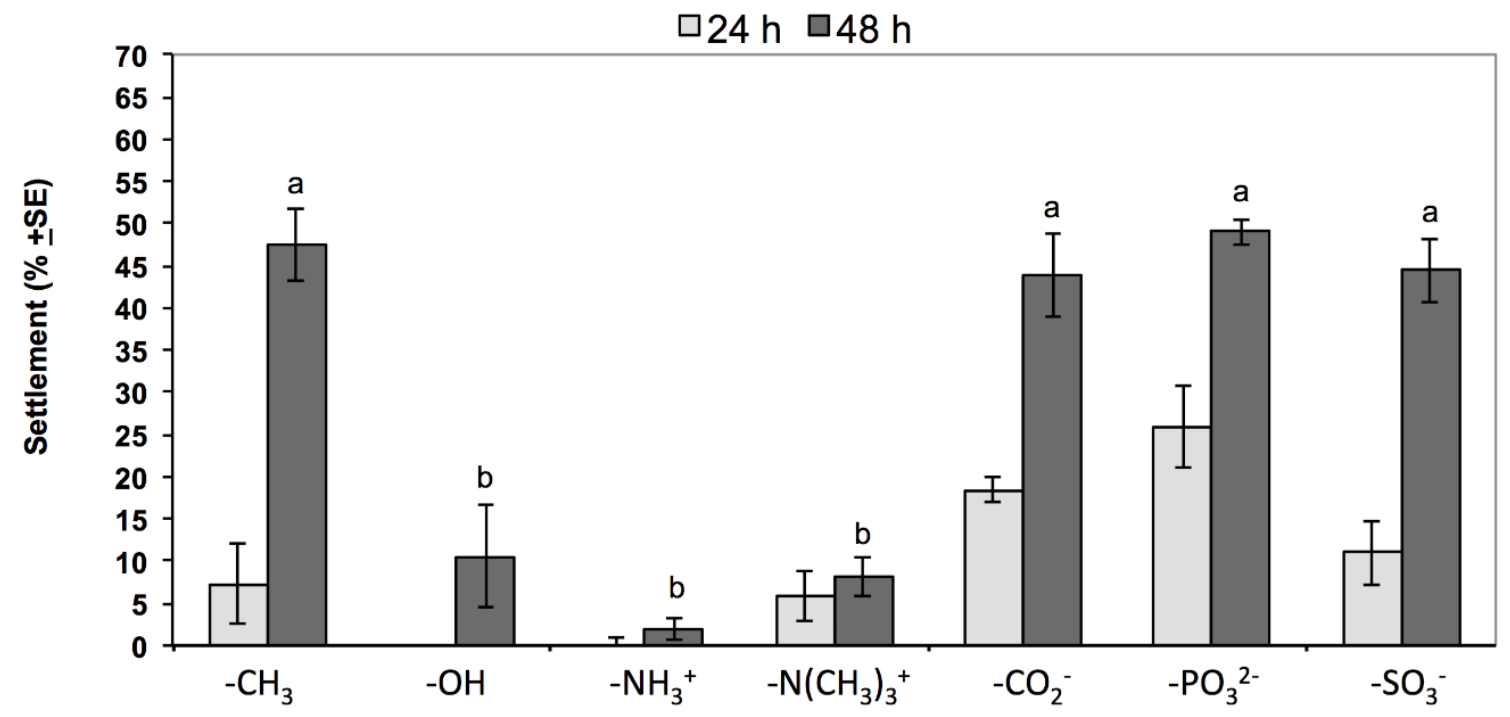

Figure 3. Settlement of cypris larvae of B. improvisus. on SAMs applied to sealed Petri dishes with 15 mL FSW (salinity=20) after 24 and $48 \mathrm{hr}$, where $-\mathrm{CH}_{3}$ is an abbreviation of $\mathrm{HS}\left(\mathrm{CH}_{2}\right)_{15} \mathrm{CH}_{3}$, - $\mathrm{OH}=$ $\mathrm{HS}\left(\mathrm{CH}_{2}\right)_{16} \mathrm{OH}, \quad-\mathrm{NH}_{3}{ }^{+}=\mathrm{HS}\left(\mathrm{CH}_{2}\right)_{16} \mathrm{NH}_{2},-\mathrm{N}\left(\mathrm{CH}_{3}\right)_{3}{ }^{+}=\mathrm{HS}\left(\mathrm{CH}_{2}\right)_{11} \mathrm{~N}\left(\mathrm{CH}_{3}\right)_{3}{ }^{+}, \quad-\mathrm{CO}_{2}^{-} \quad(\mathrm{TSA})=$ $\mathrm{HSC}_{6} \mathrm{H}_{4} \mathrm{COOH},-\mathrm{PO}_{3}{ }^{2-}=\mathrm{HS}\left(\mathrm{CH}_{2}\right)_{11} \mathrm{PO}(\mathrm{OH})_{2}$ and $-\mathrm{SO}_{3}^{-}=\mathrm{HS}\left(\mathrm{CH}_{2}\right)_{11} \mathrm{SO}_{3} \mathrm{Na}$. Tukey pairwise comparisons are presented. Means that do not share a letter are significantly different. 
Table 1. Measurements of advancing contact angles with three liquids in polystyrene (PS) Petri dishes and on SAMs applied to Petri dishes $\left(\theta_{\mathrm{W}}, \theta_{\mathrm{DIM}}, \theta_{\mathrm{G}}\right)$, surface free energy (SFE); $(\gamma)$ estimated by the GvOC approach and ellipsometric thickness. Data for $-\mathrm{CH}_{3},-\mathrm{OH},-\mathrm{N}\left(\mathrm{CH}_{3}\right)_{3}{ }^{+}$, and $-\mathrm{CO}_{2}{ }^{-}$are reproduced from Petrone et al. (2011).

\begin{tabular}{|c|c|c|c|c|c|}
\hline \multirow[t]{2}{*}{ Surface } & \multicolumn{3}{|c|}{ Advancing contact angle ${ }^{\circ}$} & \multirow{2}{*}{$\begin{array}{l}\text { SFE / } \\
\text { mJ m }{ }^{-2} \\
\gamma\end{array}$} & \multirow[t]{2}{*}{ Thickness / Å } \\
\hline & $\theta_{\mathrm{w}}$ & $\theta_{\text {DIM }}$ & $\theta_{\mathrm{G}}$ & & \\
\hline PS & $79 \pm 3$ & $26 \pm 3$ & $54 \pm 2$ & 46 & - \\
\hline$-\mathrm{CH}_{3}$ & $107 \pm 1$ & $77 \pm 1$ & $83 \pm 2$ & 19 & $18.4 \pm 0.2$ \\
\hline$-\mathrm{OH}$ & $39 \pm 2$ & $38 \pm 3$ & $18 \pm 2$ & 41 & $21.3 \pm 0.2$ \\
\hline$-\mathrm{N}\left(\mathrm{CH}_{3}\right)_{3}{ }^{+}$ & $60 \pm 2$ & $28 \pm 3$ & $50 \pm 3$ & 45 & $14.3 \pm 0.5$ \\
\hline$-\mathrm{NH}_{3}^{+}$ & $47 \pm 2$ & $32 \pm 3$ & $49 \pm 2$ & 43 & $20.8 \pm 0.5$ \\
\hline$-\mathrm{CO}_{2}^{-}(\mathrm{TSA})$ & $56 \pm 3$ & $19 \pm 2$ & $21 \pm 2$ & 48 & $3.8 \pm 0.4$ \\
\hline$-\mathrm{PO}_{3}{ }^{2-}$ & $63 \pm 1$ & $37 \pm 2$ & $50 \pm 1$ & 37 & $25.1 \pm 0.4$ \\
\hline$-\mathrm{SO}_{3}^{-}$ & $41 \pm 3$ & $41 \pm 3$ & $37 \pm 1$ & 40 & $20.6 \pm 0.3$ \\
\hline
\end{tabular}

On comparison of present data with those presented by Petrone et al. (2011), close similarity was noted between the settlement response of cyprids of B. amphitrite and B. improvisus to the range of surfaces under investigation. A general linear model (GLM) was used to illustrate these similarities. Taken together, the data satisfied the assumptions of normality and homogeneity of variance required for this test.

The results of the GLM indicated a significant effect of species $(F=6.15 p=0.021)$, with generally higher settlement of $B$. improvisus across the range of surfaces. Given the differences in assay method and period of time between conducting the two assays, however, this result is not considered to be particularly informative. What was of special interest was the relative response of the two species to the physicochemical properties of the surfaces. SFE did not influence settlement significantly $(F=1.48 p=0.235)$. On the contrary, charge exerted a significant effect $(F=4.08 p=0.03)$ with both species settling in greater numbers on negatively charged surfaces. The interaction between SFE and species produced a significant result $(F=$ $10.41 p=0.004)$, suggesting a difference in the way that the two species respond to SFE. This result may be explained by the far higher settlement of $B$. improvisus cyprids on the $\mathrm{CH}_{3} \mathrm{SAM}$ compared to the $\mathrm{OH}$ SAM; a difference that was much reduced, although nevertheless significant (Petrone et al. 2011) for B. amphitrite. The interaction between charge and species was not significant $(F=0.13 p=0.876)$; both species responded similarly to surface charge. The clustering suggested by these results can be seen clearly in an overlay of the two data sets (Figure 4).

\section{Discussion}

Initial B. improvisus cyprid settlement assays were carried out in PS 24-well plates to reduce the inherent variability in sessile drop assays on flat surfaces (Aldred et al. 2010a, Petrone et al. 2011, 2013). Each well of a PS 24-well plate had 2 mL of FSW added containing 20 cyprids. However, settlement assays carried out in PS well plates resulted in negligible cyprid settlement after $48 \mathrm{~h}$ (see Fig. 1A) due to cyprids becoming trapped at the air/seawater interface.

The phenomenon of 'floating cyprids' in conventional 24-well plate settlement assays (Qiu et al. 2008) is particularly problematic in assays involving B. improvisus. Observations in initial assays suggested that very few cyprids $(<10 \%)$ were able to actively explore the bottom 
of the wells, with most remaining trapped in the meniscus. The causes of this effect, and the reasons for differences observed among species of barnacle cyprids, are unknown. However, it is likely a combination of factors, such as the nature and efficiency of the culture filtration procedure and the natural hydrophobicity of the cyprid cuticle. When first observed by Pyefinch \& Mott (1948) during assays with cyprids of $B$. crenatus, the issue was resolved by filling assay bottles to the brim and closing with the lid. Since the problem was found only with this species and not with the larger cyprids of B. balanoides (= Semibalanus balanoides) that became the model barnacle species of the 1970s and '80s (Holm 2012), little further research on this technical issue was conducted. As B. amphitrite became established as a laboratory test species, however, methods to address 'floating' were developed since this species is affected, albeit to a lesser degree. Qiu et al. (2008) suggested that the size and relative strength of cyprids from the different species may explain why smaller cyprids of $B$. crenatus and B. amphitrite may be more prone to floating than those of $S$. balanoides or Megabalanus spp., having a proportionally larger surface area in contact with the air-water interface and reduced strength to break free. Although plausible, this explanation does not completely explain why there are such stark differences in the frequency of floating between species with similar-sized cyprids, such as Elminius modestus where floating is highly problematic and B. amphitrite where it is relatively less common. Variation in the behaviour of cyprids (encountering the meniscus more frequently, for example) or differences in the composition/physical nature of the cuticle may further explain the phenomenon. Similar findings were described by Petrone et al. (2013), comparing settlement results from a sessile drop assay, glass vials and opposed glass surfaces.

In recognition of the effect of this phenomenon on the results of cyprid assays, particularly those using species highly prone to floating, Qiu et al. (2008) designed an assay format that used filled and hermetically sealed Petri dishes; essentially a modification of the method used by Pyefinch \& Mott (1948). This method was adopted in this work with $B$. improvisus and demonstrated a marked improvement in the reliability of the assay result compared to more conventional approaches. Settlement tests were conducted in PS Falcon ${ }^{\mathrm{TM}}$ 1006 Petri dishes, which provide a hermetic seal when closed and thus a suitable environment for swimming and surface exploration by cyprids. In so doing, floating was entirely avoided and all cyprids were actively involved in the assay.

Using this modified assay method, cyprids of 0-, 1-, 2-, 3-, 4- and 5-days-old were used to observe the effects of short-term cold storage on subsequent settlement (Rittschof et al. 1984; O'Connor \& Richardson 1994; Head et al. 2004). The results in Fig. 2 show significant differences between the settlement recorded using cyprids 0-, 1-, 2- and 5-days-old compared to 3- and 4-days-old. Dahlström et al. (2000) observed that storage of cyprids of B. improvisus for more than $24 \mathrm{~h}$ decreased settlement by more than $50 \%$. Although this dramatic effect was not observed, younger cyprids (0-day-old) were nevertheless preferred for use in assays, which enabled comparison with previous studies. The higher settlement of 5-day-old cyprids is consistent with reduced discrimination with age (Rittschof et al. 1984) and depletion of energy reserves (Tremblay et al. 2007); the cyprids become more 'desperate' to settle, i.e. the desperate larva hypothesis (Toonen \& Pawlik 1994).

Self-assembled monolayers applied to PS Petri dishes (bottom and lid), provided considerable flexibility for modulation of the surface physicochemical features to which cyprids were exposed. Cyprids settled more along the sides of Petri dish during the first $24 \mathrm{~h}$, while on the bottom and lid settlement increased after $48 \mathrm{~h}$. For the purposes of this discussion, it is assumed that the $\mathrm{CH}_{3}$ - and $\mathrm{OH}$-terminated SAMs do not carry significant surface charge at the $\mathrm{pH}$ of seawater. Whereas this is almost certainly the case for the OH-SAM, it is possible that the $\mathrm{CH}_{3}-\mathrm{SAM}$ may carry a negative charge in seawater due to preferential adsorption of hydroxyl/hydronium ions. Considering the paucity of relevant experimental data, however, these two SAMs are referred to here as 'neutral'. 
The range of chemistries used in these experiments demonstrated the importance of the effect of surface charge and, more broadly, of surface energy towards settlement of cyprids. Previous work with cyprids of Balanus amphitrite focused upon the correspondence between settlement and high surface wettability (Rittschof \& Costlow 1989; Gerhart et al. 1992; Roberts et al. 1991). O'Connor and Richardson (1994) compared the settlement of $B$. amphitrite and $B$. improvisus and found that $B$. improvisus settled in higher numbers on a hydrophobic surface (polystyrene) rather than on a hydrophilic surface (borosilicate glass), while $B$. amphitrite showed the opposite trend, thus supporting the view that these organisms demonstrate opposite preferences. However, Petrone et al. (2011) later demonstrated that when well-characterised surfaces are used in conjunction with an optimised assay method, the opposite response could be observed. In fact, cyprids of $B$. amphitrite 'preferred' low $\mathrm{SFE} \mathrm{CH}_{3}$ surfaces, aligning the behaviour of B. amphitrite to that of B. improvisus. Dahlström et al. (2004) also conducted assays on hydrophilic (glass) and hydrophobic (PS) surfaces revealing a preference of cyprids of $B$. improvisus for settling on non-polar, hydrophobic surfaces. The present results for $B$. improvisus support this conclusion and suggest that the preferences of these two species in response to SFE and charge are actually similar. Cyprids of B. improvisus were observed to settle in higher numbers on non-polar, low-SFE $\mathrm{CH}_{3}$-SAMs, compared to high-SFE OHterminated SAMs.

SFE, therefore, seemed to influence the settlement of both species in a similar way. In addition, those surfaces that carried a negative charge at the $\mathrm{pH}$ of seawater $\left(\mathrm{CO}_{2}^{-}-, \mathrm{PO}_{3}{ }^{2-}\right.$ - and $\mathrm{SO}_{3}{ }^{-}$-terminated SAMs) showed high cyprid settlement for both species (despite having highSFE). Positively charged surfaces received low settlement for both species. Surface charge therefore seems to have more influence over the decision to settle than SFE alone, with negative charge overriding whatever selection criterion prevented cyprids from settling in high numbers onto neutrally charged high-energy surfaces.

The GLM and data presented in Figure 4 support the conclusion that the two species studied to date in fact share very similar preferences with regard to charge and SFE. However, the magnitude of the difference in settlement between high and low SFE neutrally charged surfaces was far higher for $B$. improvisus. This observation, in conjunction with ambiguous results from $B$. amphitrite in previous studies, is probably the source of the widely held belief that these two species have opposite responses to SFE. In summary, it seems that charge is the overwhelming physicochemical stimulus and only when the surface charge is neutral do the organisms respond directly to SFE. To fully understand the ecological implications of this result, the question must be asked, how many naturally occurring surfaces carry a neutral charge? If the answer is very few, then perhaps the role of SFE in the decision-making process of cyprids at settlement has been overestimated.

The reduced settlement on positively-charged surfaces for both $B$. amphitrite and $B$. improvisus remains unexplained, but may be a consequence of reduced tenacity during temporary adhesion/surface exploration (Aldred et al. 2011). The effect is demonstrated clearly however by settlement onto the $\mathrm{N}\left(\mathrm{CH}_{3}\right)_{3}{ }^{+}$- and $\mathrm{CO}_{2}{ }^{-}$-terminated SAMs, which have similar surface free energy of 45 and $48 \mathrm{~mJ} \mathrm{~m}^{-2}$ respectively (see Table1), but opposite charges. Settlement on these surfaces was significantly different with over four times as many cyprids settling on the latter.

It is evident that when the charge is neutral total surface energy is a predictor of cyprid settlement to surfaces with two species assayed (B. amphitrite and B. improvisus) under controlled conditions demonstrating a consistent response. Furthermore, the responses of cyprids of the two species to surface charge are also consistent, raising an important question: what is the mechanism by which surface charge modulates settlement? Maki et al. (1994) rejected a correlation between surface wettability and temporary adhesion strength of cypris 
larvae of B. amphitrite, however it would perhaps be instructive to repeat these experiments using well-characterised surfaces such as SAMs. Importantly, similar experiments must be undertaken to identify if temporary adhesion is affected by surface charge, as was suggested by observations of cyprid exploration on charged surfaces by Aldred et al. (2011). All available evidence currently points to negatively charged surfaces binding cyprid temporary adhesive strongly, providing a firm attachment and thus promoting settlement.

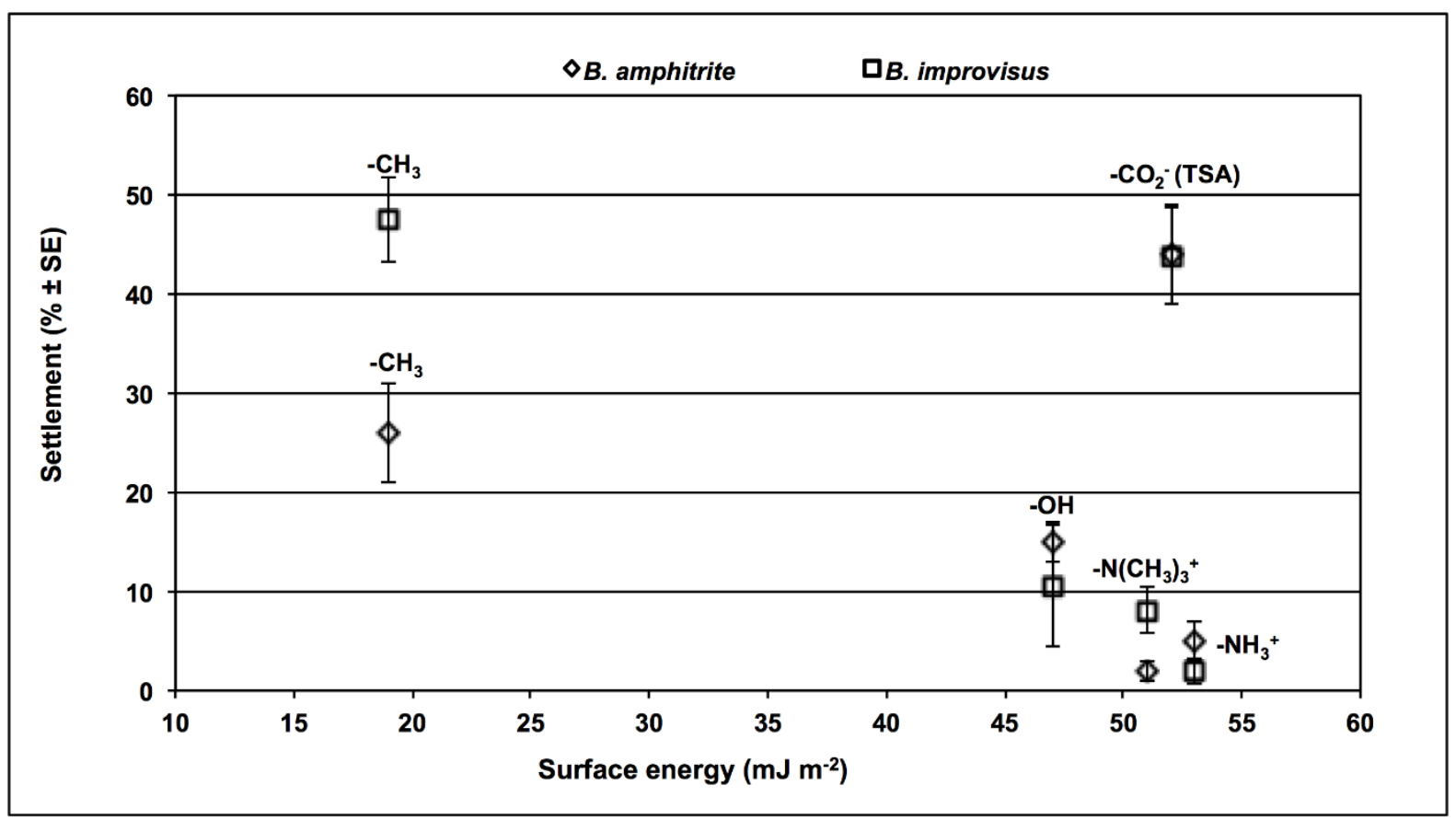

Figure 4. Settlement percentage of cypris larvae of B. improvisus used in this work and B. amphitrite from a previous experiment (Petrone et al. 2011) where $-\mathrm{CH}_{3}$ is an abbreviation of $\mathrm{HS}\left(\mathrm{CH}_{2}\right)_{15} \mathrm{CH}_{3},-\mathrm{OH}$ $=\mathrm{HS}\left(\mathrm{CH}_{2}\right)_{16} \mathrm{OH}, \quad-\mathrm{NH}_{3}{ }^{+}=\mathrm{HS}\left(\mathrm{CH}_{2}\right)_{16} \mathrm{NH}_{2},-\mathrm{N}\left(\mathrm{CH}_{3}\right)_{3}{ }^{+}=\mathrm{HS}\left(\mathrm{CH}_{2}\right)_{11} \mathrm{~N}\left(\mathrm{CH}_{3}\right)_{3}{ }^{+},-\mathrm{CO}_{2}{ }^{-}(\mathrm{TSA})=$ $\mathrm{HSC}_{6} \mathrm{H}_{4} \mathrm{COOH}$.

To summarise, this study used a modified assay method and well-defined surfaces to identify effects of both SFE and surface charge on the settlement of B. improvisus. The effects of charge and SFE were both conserved between two different species of barnacle, improving the prospect of designing inert surfaces with inhibitory characteristics that will deter multiple barnacle species. These experiments in combination with similar tests on further species, adhesion measurements and assays of pre-settlement behaviour may therefore significantly improve our understanding of the factors controlling barnacle settlement and assist the development of barnacle-resistant coatings for marine applications.

\section{Acknowledgements}

This study has received funding from the European Community's Seventh Framework Programme FP7/2007-2013 under Grant Agreement number 237997 (SEACOAT). Nick Aldred was funded by Office of Naval Research grant N00014-08-1-1240 to A.S. Clare and was supported also by COST Action TD0906. The authors acknowledge Bo Thunèr for his technical assistance with the metal evaporator, and Prof. Per Jonsson, Department of Biological and Environmental Sciences, The Sven Lovén Centre for Marine Sciences, Tjärnö, University of Gothenburg, for barnacle brood-stock. 


\section{References}

Ahmed N, Murosaki T, Kakugo A, Kurokawa T, Gong JP, Nogata Y. 2011. Long-term in situ observation of barnacle growth on soft substrates with different elasticity and wettability. Soft Matter 7:7281-7290.

Aldred N, Clare AS. 2008. The adhesive strategies of cyprids and development of barnacleresistant marine coatings. Biofouling 24:351-363.

Aldred N, Ekblad T, Andersson O, Liedberg B, Clare AS. 2011. Real-time quantification of microscale bioadhesion events in situ using imaging surface plasmon resonance (iSPR). ACS App Mater Interfaces 3:2085-2091.

Aldred N, Gohad NV, Petrone L, Orihuela B, Liedberg B, Ederth T, Mount A, Rittschof D, Clare AS. 2013. Confocal microscopy-based goniometry of barnacle cyprid permanent adhesive. J Exp Biol 216:1969-1972.

Aldred N, Ista LK, Callow ME, Callow JA, Lopez GP, Clare AS. 2006. Mussel (Mytilus edulis) byssus deposition in response to variations in surface wettability. J R Soc Interface 3:37-43.

Aldred N, Li GZ, Gao Y, Clare AS, Jiang SY. 2010a. Modulation of barnacle (Balanus amphitrite Darwin) cyprid settlement behavior by sulfobetaine and carboxybetaine methacrylate polymer coatings. Biofouling 26:673-683.

Aldred N, Scardino A, Cavaco A, de Nis R, Clare AS. 2010b. Attachment strength is a key factor in the selection of surfaces by barnacle cyprids (Balanus amphitrite) during settlement. Biofouling 26:287-299.

Andersson M, Berntsson K, Jonsson P, Gatenholm P. 1999. Microtextured surfaces: towards macrofouling resistant coatings. Biofouling 14:167-178.

Baier RE, Meyer AE. 1992. Surface analysis of fouling resistant marine coatings. Biofouling 6:165-180.

Berglin M, Larsson A, Jonsson PR, Gatenholm P. 2001. The adhesion of the barnacle, Balanus improvisus, to poly(dimethylsiloxane) fouling-release coatings and poly(methyl methacrylate) panels: The effect of barnacle size on strength and failure mode. J Adhes Sci Technol 15:14851502.

Berntsson KM, Andreasson H, Jonsson PR, Larsson L, Ring K, Petronis S, Gatenholm P. 2000a. Reduction of barnacle recruitment on micro-textured surfaces: Analysis of effective topographic characteristics and evaluation of skin friction. Biofouling 16:245-261.

Berntsson KM, Jonsson PR, Lejhall M, Gatenholm P. 2000b. Analysis of behavioural rejection of micro-textured surfaces and implications for recruitment by the barnacle Balanus improvisus. J Exp Mar Biol Ecol 251:59-83. 
Berntsson KM, Jonsson PR. 2003. Temporal and spatial patterns in recruitment and succession of a temperate marine fouling assemblage: A comparison of static panels and boat hulls during the boating season. Biofouling 19:187-195.

Berntsson KM, Jonsson PR, Larsson AI, Holdt S. 2004. Rejection of unsuitable substrata as a potential driver of aggregated settlement in the barnacle Balanus improvisus. Mar Ecol Prog Ser. 275:199-210.

Bielecki J, Chan BKK, Hoeg JT, Sari A. 2009. Antennular sensory organs in cyprids of balanomorphan cirripedes: standardizing terminology using Megabalanus rosa. Biofouling 25:203-214.

Bressy C, Hellio C, Marechal JP, Tanguy B, Margaillan A. 2010. Bioassays and field immersion tests: a comparison of the antifouling activity of copper-free poly(methacrylic)based coatings containing tertiary amines and ammonium salt groups. Biofouling 26:769-777.

Callow JA, Callow ME, Ista LK, Lopez G, Chaudhury MK. 2005. The influence of surface energy on the wetting behaviour of the spore adhesive of the marine alga Ulva linza (synonym Enteromorpha linza). J R Soc Interface 2:319-325.

Callow ME, Fletcher RL. 1994. The influence of low surface-energy materials on bioadhesion - a review. Int Biodeter Biodegr 34:333-348.

Carlton JT, Newman WA, Pitombo FB. 2011. Barnacle Invasions: Introduced, Cryptogenic, and Range Expanding Cirripedia of North and South America. In: Galil BS, Clark PF, Carlton JT, editors. In the wrong place - alien marine crustaceans: distribution, biology and impacts. Dordrecht: Springer; p.159-213.

Clare AS. 1998. Towards nontoxic antifouling. J Mar Biotechnol 6:3-6.

Clare AS, Aldred N. Surface colonisation by marine organisms and its impact on antifouling research. In: Hellio C; Yebra D, editors. Advances in Marine Antifouling Coatings and Technologies. Oxford: Woodhead Publishing; 2009, p.46-79.

Clare AS, Freet RK, McClary M. 1994. On the antennular secretion of the cyprid of Balanus amphitrite amphitrite, and its role as a settlement pheromone. J Mar Biol Assoc UK 74:243250 .

Clare AS, Nott JA. 1994. Scanning-electron-microscopy of the 4th antennular segment of Balanus amphitrite amphitrite. J Mar Biol Assoc UK 4:967-970.

Dahlström M, Martensson LGE, Jonsson PR, Arnebrant T, Elwing H. 2000. Surface active adrenoceptor compounds prevent the settlement of cyprid larvae of Balanus improvisus. Biofouling 16:191-203.

Dahlström M, Jonsson H, Jonsson PR, Elwing H. 2004. Surface wettability as a determinant in the settlement of the barnacle Balanus Improvisus (DARWIN). J Exp Mar Biol Ecol 305:223232. 
del Campo A, Schwotzer W, Gorb SN, Aldred N, Santos R, Flammang P. 2013. Preface. In: Santos R, Aldred N, Gorb S, Flamming P editors. Biological and biomimetic adhesives: challenges and opportunities. Cambridge (UK): RSC Publishing; p. 7-16.

Dexter SC. 1979. Influence of substratum critical surface-tension on bacterial adhesion - insitu studies. J Colloid Interf Sci 70:346-354.

Finlay JA, Bennett SM, Brewer LH, Sokolova A, Clay G, Gunari N, Meyer AE, Walker GC, Wendt DE, Callow ME, Callow JA, Detty MR. 2010. Barnacle settlement and the adhesion of protein and diatom microfouling to xerogel films with varying surface energy and water wettability. Biofouling 26:657-666.

Gerhart DJ, Rittschof D, Hooper IR, Eisenman K, Meyer AE, Baier RE, Young C. 1992. Rapid and inexpensive quantification of the combined polar components of surface wettability: application to biofouling. Biofouling 5:251-259.

Greco G, Lanero T. Svaldo, Torrassa S, Young R, Vassalli M, Cavaliere A, Rolandi R, Pelucchi E, Faimali M, Davenport J. 2013. Microtopography of the eye surface of the crab Carcinus maenas: an atomic force microscope study suggesting a possible antifouling potential. J R Soc Interface 10:20130122.

Head RM, Berntsson KM, Dahlström M, Overbeke K, Thomason JC. 2004. Gregarious settlement in cypris larvae: The effects of cyprid age and assay duration. Biofouling 20:123128.

Jonsson PR, Berntsson KM, Larsson AI. 2004. Linking larval supply to recruitment: Flowmediated control of initial adhesion of barnacle larvae. Ecology 85:2850-2859.

Kamino K. 2013. Mini-review: Barnacle adhesives and adhesion. Biofouling. 29:735-749

Lindner E. 1992. A low surface free energy approach in the control of marine biofouling. Biofouling 6:193-205.

Maki JS, Yule AB, Rittschof D, Mitchell R. 1994. The effect of bacterial films on the temporary adhesion and permanent fixation of cypris larvae, Balanus amphitrite Darwin. Biofouling $8: 121-131$.

Maruzzo D, Conlan S, Aldred N, Clare AS, Hoeg JT. 2011. Video observation of surface exploration in cyprids of Balanus amphitrite: the movements of antennular sensory setae. Biofouling 27:225-239.

Matsumura K, Mori S, Nagano M, Fusetani N. 1998. Lentil lectin inhibits adult extract-induced settlement of the barnacle, Balanus amphitrite. J Exp Zool 280:213-219.

Moore HB, Frue AC. 1959. The settlement and growth of Balanus improvisus, B. eburneus and B. amphitrite in the Miami area. Bull Mar Sci 9:421-440.

Murosaki T, Noguchi T, Kakugo A, Putra A, Kurokawa T, Furukawa H, Osada Y, Gong J P, Nogata Y, Matsumura K, Yoshimura E, Fusetani N. 2009. Antifouling activity of synthetic 
polymer gels against cyprids of the barnacle (Balanus amphitrite) in vitro. Biofouling 25:313320.

Nott JA. 1969. Settlement of barnacle larvae: surface structure of the antennular attachment disc by scanning electron microscopy. Mar Biol 2:248-251.

Nott JA, Foster BA. 1969. On the structure of the antennular attachment organ of the cypris larva of Balanus balanoides (L.). Philos Trans R Soc Lond, B 256:115-134.

O'Connor NJ, Richardson DL. 1994. Comparative attachment of barnacle cyprids (Balanus amphitrite Darwin, 1854, B. improvisus Darwin, 1854, and B. eburneus Gould, 1841) to polystyrene and glass substrata. J Exp Mar Biol Ecol 183:213-225.

O'Connor NJ, Richardson DL. 1996. Effects of bacterial films on attachment of barnacle (Balanus improvisus Darwin) larvae: Laboratory and field studies. J Exp Mar Biol Ecol 206:6981.

Ödling K, Albertsson C, Russell JT, Martensson LGE. 2006. An in vivo study of exocytosis of cement proteins from barnacle Balanus improvisus (D.) cyprid larva. J Exp Biol 209:956-964.

Petrone L, Di Fino A, Aldred N, Sukkaew P, Ederth T, Clare AS, Liedberg B. 2011. Effects of surface charge and Gibbs surface energy on the settlement behaviour of barnacle cyprids (Balanus amphitrite). Biofouling 27:1043-1055.

Petrone L, Lee SSC, Teo SLM, Birch WR. 2013. A novel geometry for a laboratory-based larval settlement assay. Biofouling 29:213-221.

Petrone L. 2013. Molecular surface chemistry in marine bioadhesion. Adv Colloid Interface Sci 195-196:1-18.

Pinori E, Elwing H, Berglin M,. 2011. The impact of coating hardness on the anti-barnacle efficacy of an embedded antifouling biocide. Biofouling. 29:763-773.

Pyefinch KA, Mott JC. 1948. The sensitivity of barnacles and their larvae to copper and mercury. J Exp Biol 25:276-298.

Qiu JW, Hung OS, Qian PY. 2008. An improved barnacle attachment inhibition assay. Biofouling 24:259-266.

Rittschof D, Costlow JD. 1989. Bryozoan and barnacle settlement in relation to initial surface wettability a comparison of laboratory and field studies. Sci Mar 53:411-416.

Rittschof D, Branscomb ES, Costlow JD. 1984. Settlement and behavior in relation to flow and surface in larval barnacles, Balanus amphitrite Darwin. J Exp Mar Biol Ecol 82:131-146.

Roberts D, Rittschof D, Holm E, Schmidt AR. 1991. Factors influencing initial larval settlement - temporal, spatial and surface molecular-components. J Exp Mar Biol Ecol 150:203-221. 
Salta M, Wharton J A, Stoodley P, Dennington S P, Goodes L R, Werwinski S, Mart U, Wood R J K, Stokes K R. 2010. Designing biomimetic antifouling surfaces. Phil Trans R Soc Lond, B 368:4729-4754.

Scardino AJ, de Nys R. 2011. Mini review: Biomimetic models and bioinspired surfaces for fouling control. Biofouling 27:73-86.

Stewart RJ, Ransom TC, Hlady V. 2011. Natural underwater adhesives. J Polym Sci Pol Phys 49:757-771.

Toonen RJ, Pawlik JR. 1994. Foundations of gregariousness. Nature 370:511-512.

Tremblay R, Olivier F, Bourget E, Rittschof D. 2007. Physiological condition of Balanus amphitrite cyprid larvae determines habitat selection success. Mar Ecol Prog Ser 340:1-8.

Walker G, Yule AB. 1984. Temporary adhesion of the barnacle cyprid: the existence of an antennular adhesive secretion. J Mar Biol Assoc UK 64:679-686.

Woods Hole Oceanographic Institution (1952). Marine Fouling and its Prevention. Naval Institute Press, Annapolis, MD, p 97.

Yebra DM, Kiil S, Dam-Johansen K. 2004. Antifouling technology - past, present and future steps towards efficient and environmentally friendly antifouling coatings. Prog Org Coat 50:75-104. 